\title{
PENERAPAN READING GUIDE DENGAN MEDIA BLOG CONTEXTUAL CONTENT DALAM MENINGKATKAN DAYA BERFIKIR KRITIS PADA MAHASISWA IKIP BUDI UTOMO MALANG
}

\author{
Feri Candra Setiawan \\ Ferdinan Bashofi \\ Prodi Pendidikan Sejarah dan Sosiologi \\ IKIP Budi Utomo Malang \\ Jalan Citandui 46 Malang
}

\begin{abstract}
This research aims to determine the effect of applying learning model of reading guide with blog contextual content media on students majoring in history at IKIP Budi Utomo Malang. The sample in this research is the students of history class 2017 IKIP Budi Utomo Malang.This research is a kind of Quasi experimental design and this research including with pre-test and post-test control group design.The research of African history learning with the model of reading guide with media blog contextual content is stated enough to give effect even in low level. This is indicated by: (1) the students' critical thinking ability exceeds minimalcompletenesseither individually or classically, (2) the critical thinking skill of students who are given the model of reading guide with contextual content blog media is better than the class given conventional learning, (3) variable Reading Guide sig $=0.087=8.7 \%>$ $5 \%$, so $\mathrm{H}_{0}$ is accepted, meaning that the reading guide has no influence on the variable of critical thinking ability, but Blog Contextual content variable there is positive influence with index sig $=0,030=0 \%$ $<5 \%$ so $\mathrm{H}_{0}$ is rejected, it means Contextual Content Blog has influence to critical thinking ability variable or together between reading guide model and blog contextual content media to critical thinking ability, and (4) improvement of critical thinking ability of students who are given learning model of reading guide with media blog contextual content is better than the class that is given conventional learning.
\end{abstract}

Keywords: Reading Guide, Blog Contextual Content, Critical Thinking.

Pendidikan merupakan suatu bagian dalam pengembangan mutu pembangunan secara nasional untuk menciptakan sumber daya manusia yang berkualitas. Kualitas seseorang sangat berpengaruh terhadap pola perilaku dilihat dari sikap dan tingkah laku yang didasarkan pada pelatihan dan pengajaranya. Sehingga menurut Hamalik (2013: 3) pendidikan adalah sebuah proses dengan tujuan mempengaruhi peserta didik supaya dapat menyesuaikan diri dengan lingkungannya dan mampu menimbulkan perubahan dalam dirinya baik yang bersifat akademis maupun non akademis untuk mempengaruhi perubahan bagi masyarakat di sekitarnya. Peningkatan kualitas SDM akan terbentuk apabila diselenggarakan kegiatan belajar mengajar yang baik. Karena proses interaksi belajar mengajar merupakan bagian utama dalam kegiatan pendidikan. Penyelenggaran pembelajaran adalah tugas inti dari seorang pendidik yang dapat diartikan sebagai kegiatan untuk membelajarkan peserta didiknya (Dimyanti, 2006:105).
Selama ini pembelajaran ditingkat Perguruan tinggi yang seharusnnya menjadikan para mahasiswanya memiliki kemampuan berfikir kritis yang tinggi cenderung menurun karena budaya literasi peserta didik yang rendah, perkembangan teknologi informasi membuat mahasiswa lebih memilih menyelesaikan suseatu dengan cara yang instan dengan mengambil mentah-mentah apa yang tersedia di sebuah blog atau website tanpa membaca secara detail dan mengkritisi isi dari apa yang mereka ambil. Oleh karena itu dosen perlu melakukan sebuah inovasi dalam kegiatan pembelajaran dengan memanfaat sumber dan media pembelajaran yang sesuai dengan perkembangan teknologi serta dalam penggunaannya dapat berjalan beriringan dengan perkembangan kemampuan berfikir kritis mahasiswa

Pemanfaatan sumber dan media dalam proses pembelajaran sangat penting, karena sumber belajar yang sangat kaya dengan pengetahuan jika dibandingkan dengan 
kemampuan Dosen itu sendiri. media dan sumber belajar adalah segala kondisi di luar diri mahasiswa dan Dosen baik berupa fisik maupun nonfisik yang dapat menjadi perantara agar pesan pembelajaran tersampaikan kepada siswa secara optimal. Namun penggunaan media dan sumber belajar sendiri terkadang menjadi kurang menarik tanpa disertai model yang mampu mendukung penerapan sumber dan media pembelajaran, dan begitu sebaliknya penerapan sebuah model pembelajaran seringkali juga membutuhkan sumber dan media pendukung.

Pada mata kuliah sejarah Afrika terlihat ada kekurangan pada perkuliahan awal yang selama ini dilaksanakan, khususnya dalam kegiatan pembelajaran. Beberapa mahasiswa terbiasa mendengarkan penjelasan dan berdiskusi dengan sumber yang diambil secara mentah-mentah dari sebuah blog atau website tanpa ada proses membaca secara detail dan mengkritisi isi tulisan tersebut.

Oleh karena ini perlu didesain perencanaan pembelajaran yang memadukan sebuah model dan media pembelajaran yang efektif dalam meningkatkan kemampuan berfikir kritis mahasiswa, dan Peneliti mencoba melakukan penelitian dengan memadukan Model pembelajaran Reading guide dengan media kontekstual blog untuk mengetahui tingkat perkembangan kemampuan berfikir kritis mahasiswa pada matakuliah sejarah Afrika.

\section{TINJAUANPUSTAKA}

Metode berasal dari kata method yang berarti jalan atau cara. Secara estimologi metode merupakan masalah yang menguraikan caracara atau jalan mengenai pelaksanaan secara teknis (Bagus, 1996: 635). Menurut Poerwodarminto (1998: 581), metode adalah suatu cara yang teratur berfikir baik untuk mencapai maksud dan metode dijadikan sebagai cara kerja sistematis dalam memudahkan pelaksanaan guna mencapai tujuan tertentu. Selain itu metode membentuk suatu mata rantai yang terpenting dalam hubungan kegiatan belajar mengajar yang disisi lain mempunyai tujuan dan sasaran serta mempunyai hasil dan nilai. Metode merupakan mata rantai tengah yang menghubungkan tujuan dengan hasil atau nilai metode tersebut yang pada akhirnya akan menentukan kualitas sebuah hasil (Kochar, 2008: 285).

Berdasarkan urain pendapat di atas, dapat disimpulkan bahwa metode pembelajaran merupakan suatu cara atau jalan yang digunakan untuk mengerjakan suatu tindakan dan digunakan dalam pelaksanaan kegiatan belajar mengajar untuk mencapai tujuan pembelajaran. Metode pembelajaran dalam sebuah mata pelajaran merupakan suatu alat untuk mencapai tujuan yang telah ditetapkan. Seperti halnya dalam pembelajaran sejarah dari pelaksanan metode yang diterapkan siswa memperoleh pengetahuan mengenai fakta-fakta mengenai materi yang telah disampaikan Dosen kepada mahasiswa. Sehingga mahasiswa dapat mengembangkan hubungan sebab akibat dari fakta-fakta yang ada dalam suatu peristiwa yang memudahkanya untuk memahami materi yang telah dipelajarinya.

Perkembangan model pembelajaran Weil (2000: 13) mengelompokkan model dalam nerbagai rumpun yakni model interaksi sosial, model pemrosesan informasi, model personal, model perilaku. Namun dalam kegiatan pembelajaran yang paling diutamakan yakni model pembelajaran yang berpusat pada guru dan model pembelajaran yang berpusat pada peserta didik. Model pembelajaran yang berpusat pada guru difokuskan pada tatap muka aktual antara pendidik dengan peserta didik, melalui presentasi, menerangkan dan bekerja kelompok. Model ini lebih menekankan pada model presentasi, menerangkan pengajaran secara langsung dan pengajaran melealui model konsep-konsep (Fathurrohman, 2012: 94). Sedangkan model pembelajaran yang berpusat pada peserta didik diasumsikan sebagai model yang berbeda mengenai cara mengajar dan belajar. Dalam pembelajaranya seperti Cooperative Learning yang menghasilkan peserta didik memiliki prestasi secara akademisnya. Sedangkan model diskusi kelas menghasikan peserta didik yang mampu memahami konseptual dan meningkatkan keterampilan berkomunikasi dan proses berfikir (Sagala,2010 :64).

Dari uraian diatas dapat disimpulkan bahwa model pembelajaran merupakan suatu strategi, rencana yang berpola yang digunakan sebagai acuan dalam melakukan prosese 
pembelajaran yang menciptakan proses pembelajaran yang lebih aktraktif dalam mencapai tujuan pembelajaranya. Selain itu penggunaan model pembelajaran harus sesuai dengan materi pembelajaranya agar menciptakan lingkungan belajar yang lebih kondusif sesuai dengan karakter peserta didknya. Sehingga model pembelajaran terdapat strategi dalam mencapai kompetensi peserta didik dengan mengunakan pendekatan model, metode, dan teknik dalam pembelajaranya.

Pembelajaran model Reading Guide adalah cara memandu peserta didik untuk membaca panduan yang disiapkan oleh pendidik sesuai dengan materi yang akan diajarkan dan waktu yang telah ditentukan (Zaini, 2004: 37). Dalam proses pembelajaranya model ini tidak terlalu membebani terhadap peserta didik secara keseluruhan, dimana peserta didik diharapkan mencari point-point bacaan yang telah ditentukan oleh pendidik .

Pada awal sejarah pembelajaran, media hanya merupakan alat bantu yang dipergunakan oleh seorang pendidik untuk menerangkan pelajaran. Alat bantu yang mula-mula digunakan adalah alat bantu visual, yaitu berupa sarana yang dapat memberikan pengalaman visual kepada siswa, antara lain untuk mendorong motivasi belajar, memperjelas dan mempermudah konsep yang abstrak, dan mempertinggi daya serap atau retensi belajar. Kemudian dengan berkembangnya teknologi, khususnya teknologi audio, pada pertengahan abad ke-20 muncul alat bantu audio-visual yang terutama menggunakan pengalaman yang kongkrit untuk menghindari verbalisme. Dalam usaha memanfaatkan media sebagai alat bantu, Edgar Dale mengadakan klasifikasi menurut tingkat dari yang paling kongkrit ke yang paling abstrak.(Riyana, 2012:11)

Salah satu media dan sumber belajar yang saat ini berkembang adalah media pembelajaran berbasis online yang dapat kita temukan dalam bentuk Blog atau website, dengan memanfaat jaringan internet dan perangkat digital seperti laptop atau telpon genggam kita dapat mengakses informasi di dalamnya kapanpun dan dimanapun selama tersambung dengan jaringan internet, terlebih lagi media online seperti blog atau website isi atau kontennya dapat terus diperbaharui dalam waktu singkat berbeda dengan media cetak seperti buku ketika harus direvisi harus melalui proses cetak ulang dan memakan biaya.

Dewasa ini pembelajaran yang memprioritaskan kemampuan berpikir kritis mahasiswa banyak menjadi fokus pembicaraan dalam inovasi pendidikan. Tuntutan perubahan ini muncul seiring dengan perkembangan kebutuhan akan kemampuan para pekerja di era digital saat ini. Para pekerja yang memasuki tempat kerja di masa mendatang harus memiliki berbagai kemampuan yang menjadikan mereka pemikir sistematis, pemecah masalah, pembuat keputusan yang tepat baik secara mandiri maupun kelompok dan terus belajar sepanjang hidup untuk meningkatkan profesionalisme. Penting bagi mahasiswa untuk menjadi seorang pemikir kritis sejalan dengan meningkatnya jenis pekerjaan di masa yang akan datang. (Suparni, 2016:41)

Selama ini dalam aplikasinyamahasiswa dituntut lebih mandiri yang dapat dilakukan secara individu maupun bersama rekan belajar. Pembagian materi yang jelas dan menganalisis berdasarkan point-point dapat membantu peserta didik lebih mudah untuk memahami tema yang telah ditentukan. Model ini dirasa cocok bila diterapkan pada materi yang memerlukan waktu yang banyak yang tidak mungkin untuk dijelaskan semuanya dikelas karena keterbatasan waktu

Secara khusus seorang lulusan sarjana dituntut untuk memiliki kemampuan berpikir kritis dalam mempelajari dan mempraktekkan ilmunya. Alasannya, pertama, mahasiswa merupakan bagian dari masyarakat ilmiah. Masyarakat ilmiah bekerja demi kemajuan ilmu pengetahuan dan kesejahteraan umat manusia. Ilmu pengetahuan berkembang karena adanya pertanyaan dan meragukan apa yang sudah ditemukan sebelumnya. Tanpa kemampuan berpikir kritis, mahasiswa tidak bisa mengajukan pertanyaan yang mendasar terhadap pernyataan-pernyataan ilmiah yang ada. Sebaliknya, jika mahasiswa hanya menelan penemuan dan tidak bertanya lagi, maka ilmu pengetahuan tidak berkembang.

Kedua, seorang mahasiswa, dituntut bersikap sesuai dengan bidang keahliannya, baik ketika mahasiswa sedang kuliah maupun ketika telah mendapatkan ijazah kelulusan. Sebagai 
seorang akademisi mahasiswa dituntut untuk merubah keadaan diri sendiri maupun keadaan masyarakat untuk menjadi lebih baik. Fenomena fenomena social yang ada dimasyarakat bisa dilihat dan bisa diperbaiki seorang harus bermodalkan kemampuan berfikir kritis. Menurut beberapa ahli berpikir kritis adalah memutuskan sesuatu secara hati-hati dan sengaja yang dapat berupa pernyataan menerima, menolak atau menunda sebuah keputusan/ pernyataan (Moore dan Parker, 1988:4). Secara umum berpikir kritis meliputi kegiatan: 1) Menjelaskan pernyataan yang diterima atau diajukan, 2) mengumpulkan informasi tambahan, 3) mencari informasi yang tersirat dari yang tersurat atau maksud-maksud yang tersembunyi, dan 4) mengevaluasi pernyataan berdasarkan hasil ketiga kegiatan sebelumnya. Pernyataan yang terkena oleh empat kegiatan tersebut mencakup baik pernyataan orang lain atau pernyataan diri sendiri. Keempat kegiatan tersebut tidak harus dilakukan secara berurutan. Seringkali kita dapat maju selangkah ke kegiatan berikut, kemudian mundur kembali untuk mengulang kegiatan yang sebelumnya telah dilakukan.

Kemampuan berfikir kritis tidak bisa dilakukan serta merta tanpa ada sebuah perencanaan dan kesinambungan, oleh karena maka harus ada pembiasaan-pembiasaan dalam kegiatan belajar mengajar yang mengarahkan mahasiswa untuk mengasah kemampuan berfikir kritisnya.

Kemampuan membaca sebuah media informasi secara kritismenurut Kellner dalam (Varga \& Rahella, 2011:101) melibatkan pengembangan konsep interpretasi dan kritik. Terlibat dalam penilaian dan evaluasi terhadap sebuah teks media dan memerlukan diskusi yang hati-hati terhadap kriteria kritik moral, pedagogis, politik, atau estetika tertentu. Kemampuan membaca sebuah media informasi secara kritis tidak hanya mengajarkan mahasiswa untuk belajar dari media, untuk menolak manipulasi media, dan menggunakan materi media dengan cara yang konstruktif, tetapi ini berkaitan dengan pengembangan keterampilan yang akan membantu menciptakan warga negara yang baik dan yang akan membuat mereka lebih termotivasi dan menjadi anggota masyarakat yang kompeten dalam kehidupan sosial. Singkatnya, para mahasiswa yang memiliki kemampuan berfikir kritis akan bertanya pada diri mereka sendiri tentang pertanyaan-pertanyaan berikut saat membaca teks tradisional atau digimodernis: Apa pesan (tersembunyi) itu? Apa argumennya yang ada didalamnya? Mengapa media / jenis dokumen yang dipilih? Siapa target informasi? cara yang digunakan untuk menyampaikan pesan? Apa tujuan dari media atau informasi tersebut ini?, dll.

\section{METODE}

Penelitian ini merupakan jenis penelitian eksperimental semu (Quasi eksperimental design), karena belum memenuhi persyaratan seperti cara eksperimen yang dapat dikatakan ilmiah mengikuti peraturan-peraturan tertentu (Arikunto 2012: 77). Dalam penelitian ini di kenakan perlakuan pada subjek penelitian yaitu mahasiswa di beri model pembelajaran Reading Guide, diadakan pre-test dan pos-test serta sampel yang ada di suatu kelas tertentu karena itu penelitian ini termasuk penelitian semu dengan pre-test dan pos-testcontrol group design(Sudjana.1996: 23).

Rancangan yang digunakan dalam penelitian ini adalah pretest dan posttest

Adapun model rancangan eksperimen ini dapat dilihat sebagi berikut.

Tabel.1 Desain Eksperimen

\begin{tabular}{|l|l|r|r|c|}
\hline & kelompok & pretest & Perlakuan & Posttest \\
\hline & eksperimen & $X_{E}$ & $X_{K}$ & $\mathrm{X}_{\mathrm{E}}{ }^{1}$ \\
\hline \multirow{2}{*}{ kontrol } & & $X_{K}$ & $\mathrm{Y}_{\mathrm{K}}$ & $\mathrm{X}_{\mathrm{E}}{ }^{1}$ \\
\hline
\end{tabular}

Keterangan :

$Y_{E}=$ Perlakuan pembelajaran Reading guide dengan BlogContextual Content pada kelas eksperimen

$Y_{K}=$ Perlakuan pembelajaran konvensional pada kelompok Kontrol

$X_{E}=$ Hasil pre-test kelompok eksperimen

$X_{K}=$ Hasil pre-test kelompok kontrol

$X_{E^{1}}=$ Hasil pos-test kelompok eksperimen

$X_{K^{1}}=$ Hasil pos-test kelompok kontrol

Variabel dalam penelitian ini terdiri dari variabel bebas dan variabel terikat yang menjadi variabel bebasnya adalah model reading guide serta media Blog contextual content dan variabel terikatnya adalah kemampuan berpikir kritis. 
HASIL

Dalam pembahasan statistik deskriptif ini untuk mendapatkan gambaran mengenai responden, berikut ini diuraikan pengelompokan responden berdasarkan jenis kelamin responden, usia responden dan indeks prestasi. Adapun data yang peneliti peroleh mengenai profil responden adalah sebagai berikut.

\section{Tabel.2 Karakteristik Responden Berdasarkan} Jenis Kelamin

\begin{tabular}{|l|c|c|}
\hline Jenis Kelamin & Jumlah & Presentase \\
\hline Pria & 40 & 44,44 \\
\hline Wanita & 50 & 55,55 \\
\hline Total & $\mathbf{9 0}$ & $\mathbf{1 0 0}$ \\
\hline
\end{tabular}

Berdasarkan table 2 diatas, total responden yang merupakan mahasiswa jurusan sejarah IKIP Budi Utomo Malang adalah 90 orang, jumlah responden pria sebanyak 40 orang $(44,44 \%)$ dan responden wanita sebanyak 47 orang $(55,55 \%)$, maka dapat diketahui bahwa mayoritas responden adalah wanita.

Perhitungan uji regresi untuk mengetahui pengaruh model Reading Guide dan media Blog Contextual Content terhadap kemampuan berpikir kritis digunakan regresi ganda dengan hipotesis sebagai berikut :

$H_{0}: \beta=0$ (Persamaan regresi tidak linier atau model Reading Guide dengan media Blog Contextual Content tidak berpengaruh terhadap kemampuan berpikir kreatif)

$H_{1}: \quad \beta \neq 0$ (Persamaan regresi linier atau model Reading Guide dengan media Blog Contextual Content berpengaruh terhadap kemampuan berpikir kreatif)

Berdasarkan hasil olah data diperoleh nilai $\mathrm{F}=3.918$ dan nilai $\operatorname{sig}=0,028=2,8 \%<5 \%$, berarti tolak $H_{0}$ dan terima $H_{1}$. Jadi dapat disimpulkan bahwa model Reading Guide dan media Blog Contextual Content secara bersama-sama berpengaruh positif terhadap kemampuan berpikir krisis.

Untuk melihat pengaruh masing-masing variabel independen terhadap variabel dependen dilakukan melalui uji parsial uji $t$, seperti terlihat pada output Coefficient. Hipotesis yang diajukan adalah sebagai berikut.

$H_{0}$ : koefisien regresi tidak signifikan

$H_{1}$ : koefisien regresi signifikan

Berdasarkan hasil data SPSS diperoleh nilai $a=62.838 ; b=-1.193$; dan $c=1.372$, jadi persamaan regresi ganda adalah $\hat{Y}=62.838+-1,193 X_{1}+1.372 X_{2} . \quad$ Nilai signifikan untuk variabel Reading Guidesig $=0,087$ $=8,7 \%>5 \%$, jadi $H_{0}$ diterima, artinya reading guide tidak memiliki pengaruh terhadap variabel kemampuan berpikir kritis. Sedangkan untuk variabel Blog Contextual Contentsig $=0,030=0 \%$ $<5 \%$ jadi $H_{0}$ ditolak, artinya Blog Contextual Content berpengaruh terhadap variabel kemampuan berpikir kritis. Hal ini dapat diartikan bahwa secara bersama-sama penerapan model reading guide dengan media Blog Contextual Contentmempengaruhi kemampuan berpikir kritis, namun secara parsial penerapan Reading Guide tanpa disertai media Blog Contextual Content tidak mempengaruhi kemampuan berfikir kritis.

Peningkatan kemampuan berpikir kritis didasarkan atas nilai gain. Diketahui bahwa nilai rerata postes $\left(S_{f}\right)$ kelas yang diberi penerapan model reading guide dengan media blog contextual content adalah 73,5 , sedangkan nilai rerata pretes $\left(S_{i}\right)$ kelas yang diberi penerapan model reading guide dengan media blog contextual content adalah 64,1 . Perhitungan nilai gain tersebut secara lengkap diuraikan sebagai berikut.

$$
\langle\mathrm{g}\rangle=\frac{\left(S_{f}-S_{i}\right)}{\left(100-S_{i}\right)}=\frac{(73,5-64,1)}{(100-64,1)}=0,26
$$

Jadi secara rerata diperoleh nilai gain $\langle\mathrm{g}\rangle$ sebesar 0,22 yang berarti tafsiran peningkatan kemampuan berpikir kritis pada mahasiswa yang diberi penerapan model reading guide dengan media blog contextual content adalah dalam kategori rendah.

\section{PEMBAHASAN}

Pengaruh model reading guide dan media blog contextual content terhadapkemampuan berpikir kritis menunjukkan bahwa model reading guide dan media blog contextual content bersama-sama mempengaruhi secara positif terhadap kemampuan berpikir kritis mahasiswa pada materi sejarah afrika. Jika dikaitkan dengan pembelajaran kontekstual maka hal tersebut juga sesuai dengan pendapat Nurhadi (2004:56) konsep belajar dimana Pendidik menghadirkan dunia nyata dalam bentuk media pembelajaran Bolg Contextual content yang berisi materi atau isu-isu kekinian yang berkaitan dengan sejarah Afrika kedalam kelas dan mendorong 
mmahasiswa membuat hubungan antar pengetahuan yang dimilikinya dengan menerapkan dalam kehidupan mereka seharihari sementara mahasiswa memperoleh pengetahuan dan ketrampilan dari konteks yang terbatas sedikit demi sedikit dan dari proses mengkontruksi sendiri sebagai bekal untuk memecahkan masalah dalam kehidupan sebagai anggota masyarakat".

Disisi lain, pembelajaran dengan menggunakan model reading guide dan media blog contextual content mampu menggerakkan mahasiswa untuk aktif dalam proses pembelajaran, baik dalam mengerjakan soal-soal atau diskusi dalam rangka memperoleh informasi, sehingga dapat meningkatkan keterampilan proses berfikir mahasiswa selama proses pembelajaran. Hal ini sesuai dengan pendapat Semiawan (1987: 14) yang mengatakan bahwa keterampilan proses diperlukan untuk memahami konsep yang rumit dan abstrak melalui manipulasi contoh konkrit, menggiring mahasiswa untuk bertanya, mengamati, mengadakan eksperimen, berdiskusi dan lainlain.Seperti apa yang diungkapkan oleh KellnertentangKemampuan membaca sebuah media informasi secara kritis dapat dilihat dalam proses pembelajaran yang memadukan model reading guide dengan media blog contextual content pada materi sejarah Afrika

Dengan kata lain, melalui manipulasi informasi kedalam media baru dapat membantu pemikiran mahasiswa dalam memahami suatu konsep dan memecahkan masalah yang mereka hadapi, sehingga dapat meningkatkan hasil belajar kemampuan berpikir kritis mereka. Jadi reading guide dengan media blog contextual content merupakan dua variabel yang secara bersamasama memberikan pengaruh yang positifterhadap kemampuan berpikir kritis.

Hasil uji peningkatan kemampuan berpikir kritis mahasiswa berdasarkan nilai pretes dan postes kemampuan berpikir kritis untuk kelas yang diberi penerapan model reading guide dengan media blog contextual content materi sejarah Afrika mendapatkan rerata gain sebesar 0,26 yang berarti tafsiran peningkatan kemampuan berpikir kritis termasuk dalam kategori rendah. Sedangkan untuk kelas yang diberi pembelajaran konvensional nilai rerata gain yang diperoleh adalah 0,14 yang juga dalam kategori rendah, walaupun hasil dari kedua kelas rendah tapi masih cukup untuk memberikan hasil positif terhadap peningkatan kemampuan berfikir kritis mahasiswa, rerata peningkatan pada siswa kelas yang diberi penerapan model reading guide dengan media blog contextual content lebih tinggi daripada kelas yang diberi pembelajaran konvensional, ini juga didukung melalui uji statistik yang telah dilakukan pada bahasan sebelumnya. Hal ini menunjukkan bahwa peningkatan kemampuan berpikir kritis pada mahasiswa yang memperoleh pembelajaran model reading guide dengan media blog contextual content pada materi sejarah Afrika lebih baik dibandingkan dengan mahasiswa yang memperoleh pembelajaran konvensional.

Penggunaan model reading guide dengan media blog contextual content pada materi sejarah Afrika memberikan kesempatan mahasiswa untuk saling berdiskusi dalam proses pembelajaran, selain itu kegiatan pembelajaran yang mengarahkan mahasiswa untuk saling menyelesaikan permasalahan secara kritis dalam belajar. blog contextual content yang memuat materi kesejarahan Afrikajuga melatih mahasiswa dalam mengembangkan kemampuan berpikir kritis.

Pembelajaran dalam matakuliah sejarah Afrika di IKIP Budi Utomo malang yang memiliki karakteristik mahasiswa yang unik sehingga dalam penerapan model dan media tidaklah cukup dilaksanakan 1 aau 2 kali proses pembelajaran melaikan harus berkesinambungan sehingga hasil peninggkapan kemampuan berfikir kritis mahasiswa berada padat tingkatan yang maskimal.

\section{KESIMPULAN}

Pembelajaran sejarah Afrika dengan model reading guide dengan media blog contextual content dinyatakan cukup memberikan pengaruh walaupun dalam taraf yang masih rendah. Hal ini ditunjukkan dengan: (1) kemampuan berpikir kritismahasiswa melampaui KKM baik secara individual maupun klasikal, (2) kemampuan berpikir kritismahasiswa yang diberi model reading guide dengan media blog contextual content lebih baik dari pada kelas yang diberi pembelajaran konvensional, (3) Adanya pengaruh positif secara bersama-sama antara model reading guide 
dan media blog contextual content terhadap kemampuan berpikir kritis, dan (4) peningkatan kemampuan berpikir kritis mahasiswa yang diberi pembelajaran model reading guide dengan media blog contextual content lebih baik dari pada kelas yang diberi pembelajaran konvensional.

\section{DAFTAR RUJUKAN}

Arikunto, S. 2012. Prosedur Penelitian Suatu Pendekatan Praktek. Jakarta: Rineka Cipta

Bagus, L. 1996. Kamus Filsafat. Jakarta: Gramedia.

Dimyati, M.2006. Belajar dan Pembelajaran. Jakarta: PT. Rineka Cipta.

Fathurrohman, M. 2012. Belajar dan Pembelajaran. Yogyakarta: Teras.

Hamalik, O. 2010. Proses Belajar Mengajar. Jakarta: PT Bumi Aksara

Kochar, S.K. 2008. Pembelajaran Sejarah. Jakarta : Grasindo

Moore, B. Noel \& Richard, P. 1986. Critical Thinking. California: Mayfield Publishing Co.

Nurhadi, 2014.Pembelajaran Kontekstual dan Penerapannya dalam KBK. Malang:
Universitas Negeri Malang.

Poerwadarminto, W.J.S. 1998. Kamus Besar Bahasa Indonesia. Jakarta :Balai Pustaka.

Riyana, 2012.Media Pembelajaran. Jakarta: Direktorat Jenderal Pendidikan Islam.

Sagala, S. 2010. Konsep dan Makna Pembelajaran. Bandung: Alfabeta.

Semiawan, C. 1987. Pendekatan Keterampilan Proses. Jakarta. Gramedia.

Sudjana. 1996. Metode Statistika. Bandung: Tarsito.

Suparni.2016.Upaya Meningkatkan Kemampuan Berpikir Kritis Mahasiswa Menggunakan Bahan Ajar Berbasis Integrasi Interkoneksi.Derivat,3( 2), 40-58.

Varga \& Rahella, 2011. The importance of enhancing critical thinking skill of preservice teachers. Training And Practice. 9(12), 97-106

Weil,dkk. 2000. Models of Teaching. Amerika: A. Pearson. Education Copmpany.

Zaini, dkk. (2004). Strategi Pembelajaran Aktif. Yogyakarta: CTSD 
50\|l Feri Candra, Penerapan Reading Guide ..... 